\title{
Collective Bargaining and University Librarians: Wayne State University
}

\begin{abstract}
Librarians were an integral and sometimes unwelcome part of the Wayne State University faculty unionization movement. When the university began to abrogate their faculty status because of financial difficulties in 1968, librarians sought union counsel and were later joined in union activities by the teaching faculty. During organization, librarians faced problems of fair representation, but the $A A U P$, the elected bargaining agent, ultimately negotiated a contract in 1972 which restored some of their faculty rights. Collective bargaining made WSU librarians question their traditional self-image. A paradox of the movement, however, is that librarians, active in unionizing and negotiating, are most conservative in using participatory management privileges granted them by the contract.
\end{abstract}

L IIBRARIANS HAVE BEEN AN INTEGRAL but sometimes unwelcome part of the movement for faculty unionization at Wayne State University, Detroit (WSU). Their militancy demonstrates the changing role that librarians are playing in the university community. But, most importantly, their involvement is an example of what challenges collective bargaining brings to university governance-and to university librarianship.

The Background

At Wayne, librarians traditionally have been considered members of the faculty family, though very distant relatives. They were allowed tenure, sabbatical, and other professional leaves, as well as token representation on the University Council. Some teaching faculty have always been receptive to li-

Lothar Spang is assistant to the director of libraries, Wayne State University, Detroit, Michigan. brarians attaining equal rights and equal salary levels but only under eleven-month contracts. Most teaching faculty have been resistant to allowing librarians teaching titles. Yet, despite their family differences, during the last six years the futures of both teaching faculty and librarians have become inextricably dependent upon each other. Like it or not, both groups have had to work together to achieve maximum success in collective bargaining with a university administration which year by year, primarily because of financial problems, has sought to usurp their rights and privileges.

The first major step toward unionization was taken on February 3, 1971 when the WSU Chapter of the American Federation of Teachers, Local 1295 , successfully filed a collective bargaining petition with the Michigan Employment Relations Commission (MERC) to hold a collective bargaining election on campus. This move was precipitated by what the faculty felt to be 
the university's unsatisfactory handling of salaries over a two-year period. The average across-the-board raises for faculty, including librarians, in 1969 and 1970 had been $4 \frac{11}{2}$ percent and 3 percent respectively. In addition, the university had discontinued all automatic step increases in salaries, which meant that the gap between senior faculty salaries and those of librarians and junior faculty reflected a greater disparity each successive year, since each individual's percentage increase was computed from his base salary.

The move, however, which gained unionization its newest adherents was the university's sending of letters of termination to some seventy-one faculty members during the Christmas holidays of 1971. This number included eleven librarians, four of whom had multiple year contracts, with every expectation of soon receiving tenure. Some 60 percent of the letters had been sent to faculty in the College of Liberal Arts, primarily the Department of English. The entire faculty was dismayed by the university's action because the notices had been sent to individuals whose contracts were due for renewal, and little attention had been given to individual performance or program needs. Consequently, by the time of the union elections in 1972, many of the younger teaching faculty, and especially the librarians, were ready for strong union allegiance.

Although the letters of Christmas 1971 represented the immediate motivation for unionization of the teaching faculty, the librarians' interest in unionizing had begun in April 1968. At that time, the university announced that "to establish a more modern and equitable classification plan based upon the requirements and responsibilities for the various positions involved," it was reclassifying the faculty into two separate groups, the teaching faculty and the academic staff (librarians), each with separate and not always equal rights and privileges. ${ }^{1}$ No longer would librarians automatically be assured of professional leaves, sabbaticals, or tenure. When the WSU Board of Governors in early November 1968 endorsed this new classification plan and approved an accompanying separate salary schedule, librarians immediately asked for intervention by the University Council and the local chapters of the American Association of University Professors (AAUP) and the American Federation of Teachers (AFT). The University Council did nothing; the AAUP politely expressed sympathy. A number of librarians, therefore, assumed activist roles in the Wayne Chapter of the Detroit Federation of Teachers (WSUFT) which demonstrated a constructive interest in representing librarians in their fight to regain their former faculty status with its attendant rights and privileges. One librarian became secretary of the WSUFT. Another served on the WSUFT Executive Committee. Still others served as liaisons between the WSUFT and librarians. Meanwhile, the paraprofessionals (library assistants) of the WSU Libraries, who formerly had enjoyed academic privileges including tenure, reacted to the impending reclassification by immediately affiliating with the AFLCIO Local 10, Office and Professional Employees International Union, ultimately negotiating a three-year contract with the university in late November 1969.

Librarians, as a group, were cautious in their organizing. Between 1968 and 1970 unions made several abortive attempts at petitioning the entire faculty for union representation. But many faculty, including the more seasoned librarians, resisted unionization until necessary as a last resort, preferring to maintain the traditional view of the faculty as being too "professional" for trade union tactics. However, during these two years, the faculty, and espe- 
cially librarians, became more and more disturbed by university efforts to abolish tenure rights. In November 1970 it was learned that because of impending financial exigencies the administration was rewriting the university tenure statute to give the university administration maximum flexibility. For librarians, this meant further eroding of their already precarious position. Their status had deteriorated from one of being equal in most areas to teaching faculty, except for salaries and titles, to one of no tenure, no guarantees of professional leaves, no automatic rights to sabbatical leaves, and an ever growing disparity in salaries.

When the WSUFT, correctly reading the faculty discontent over salaries and job security, petitioned for a collective bargaining election at the beginning of 1971, unionization ultimately gained massive support from librarians as well as from teaching faculty who were later to be threatened by the Christmas letters of 1971. Librarians had been at the forefront of interest in the union movement, later joined by many teaching faculty when it was seen that a united front was the only means of countering a determined university administration.

\section{Selection of a Union}

During the process of officially selecting a union to represent them in collective bargaining, WSU librarians as a group interviewed representatives from the WSU-AAUP, the WSUFT, and the Michigan Education Association (MEA) to determine which union could most effectively support librarians' efforts to regain their former status. Most librarians chose to continue association with the local chapter of the AFT, traditionally the more activist of the education unions, because it seemed most interested and able to represent their position during the MERC hearings where strong representation was essential to achievement of their goals.
MERC decisions would resolve three critical issues for librarians: Would the faculty bargaining unit include academic staff (librarians)? Would the Medical School faculty, including the Medical Library staff, have a separate bargaining unit? and Would department chairmen and supervisors be included in the unit? All three questions were important to librarians because they involved the issues of group solidarity and equal representation, crucial to a strong united front. If MERC determined all WSU librarians to be equal to teaching faculty, then salaried and other conditions of employment would be commensurate. If MERC ruled that the Medical School faculty was to be separate, then salaries and the administrative and peer relationship of some six librarians to the other fifty-four university librarians would be unequal. In addition, if MERC ruled to exclude eleven library unit heads, the other fortynine WSU librarians would lose valuable group solidarity. Librarians' strength in collective bargaining lay in their unity as a cohesive group-a block of sixty, the largest active voting block on campus with the exception of the School of Nursing and the combined departments of the College of Liberal Arts. Any division, caused by an adverse decision by MERC, might serve to weaken their bargaining position. Therefore, their hopes rested on the WSUFT's presentation of a strong case for them at the MERC hearings on February 12, 1971, and April 19, 1971.

MERC issued its long-awaited decision in February 1972, declaring that the bargaining unit would include:

All teaching faculty of Wayne State University including professors, associate professors, assistant professors, and instructors, fractional time teaching faculty who teach more than half time, all academic staff employees of Wayne State University including, intra-alia, librarians, archivists, academic advisors, counselors, but excluding adjunct 
faculty, research assistants and associates, professional and administrative staff, department chairmen in the colleges of liberal arts, Monteith, engineering, medicine and business administration, deans and other executive and supervisory employees and all other employees. ${ }^{2}$

In determining the scope of the WSU bargaining unit, MERC had adhered to the precedent set at Eastern Michigan University (EMU) one month earlier. There, it was established that the bargaining unit was to be as large as possible. Therefore, at WSU most supervisors and the Medical School faculty were included. All sixty staff librarians were represented, excluding the director, associate director, and assistant director.

In a most crucial area, however, the WSUFT had failed: MERC had designated librarians as "academic staff," separate from the teaching faculty. This decision too was based on the EMU precedent, one which established that wherever possible the existing classification schedules would be adopted. Therefore, at WSU this meant that the job classification, complete with the teaching faculty-academic staff division, established by the WSU administration in 1968 would be upheld. Unlike those at EMU, WSU librarians were no longer to be part of the faculty family.

With the union election imminent and the ballot set to include four choices, WSU-AAUP, WSUFT, MEA, and No Union, the librarians met to determine final strategy on how to counter their alienated position. Discouraged in the interest demonstrated by the WSUAAUP and the MEA at the MERC hearings, as well as by the disappointment of the WSUFT efforts, librarians as a group chose not to endorse any one union. Instead, there were two camps: those still loyal to the AFT, and those half-heartedly supporting the AAUP, the only other union that seemed to offer a promise of understanding librarians' goals. The librarians who support- ed the WSU-AAUP were either longterm members of the national AAUP, or those who felt that the AFT was too closely associated with the $\mathrm{K}-12$ public school teachers' union movement and was therefore unfamiliar with university needs. Besides the WSU-AAUP, the WSUFT, and the MEA, however, there were no other options. Adherence to a union still seemed the only means of countering a strong administration.

When MERC tabulated the results of the first election in April 1972, it found that neither the WSU-AAUP nor the WSUFT had the numerical plurality, but their combined votes represented a majority. Under Michigan law, this meant that a run-off election had to be held. The WSU-AAUP ultimately won, but only after some seventy votes, challenged mainly by the WSUFT and the university administration, were satisfactorily negotiated. When the WSUAAUP was finally certified on June 6, 1972 , with less than a unanimous mandate, librarians as a group were skeptical of the stand it would take in their behalf. Previously, the union had demonstrated little concern for them, and most librarians, like many of the teaching faculty, had voted for it either because the WSUFT had failed to gain adequate results at the MERC hearings or as a rather feeble effort to insure some semblance of a united faculty front. Once the WSU-AAUP was designated the bargaining agent, however, many librarians took active roles in preparing for negotiations. One became chairman of the Election Committee for New Officers, while others served on committees such as Faculty Affairs, University Governance, Fringe Benefits, Salary, Women's Rights, Calendar, and Academic Staff.

\section{The Negotiating Team}

Surprisingly enough, although the teaching faculty representatives of the WSU-AAUP Bargaining Council were less than enthusiastic supporters of li- 
brarians' goals and gave no promises of supporting a contract that would give them their former status or even fair consideration, librarians as well as other nonteaching faculty members were well represented on the negotiating team. The five members of the team, chosen to provide a cross section of both faculty and union representation, included a strong women's rights advocate, a founder of the Wayne AAUP chapter, a WSUFT leader (who became the WSU-AAUP chief negotiator), a University Council activist, and one nonteaching faculty member (a librarian who had negotiated the 1969 contract between library assistants and the university).

The negotiating team took full advantage of local resources in Detroit and sought the counsel of auto union leaders from Solidarity House, world headquarters of the United Automobile Workers of America, who assigned a former president of a UAW-Chrysler Local as a consultant. Under his guidance, the Wayne negotiating team spent August and early September 1972 preparing negotiating plans and actual contract clauses for issues such as university governance, tenure and promotions, leaves, faculty status, compensation, individual rights, union security, accountability (student and peer evaluation), discrimination, and use of facilities and services, as well as other controversial issues as they were brought to the attention of the negotiating team by the Executive Committee of the WSU-AAUP. These "other issues" included maternity leaves, insurance, parking, and the use of part-time staff, all issues over which the faculty, including librarians, had long been at variance with the university. Procedurally, the Executive Committee received all contract demands from the various units on campus, discussed their merits in a bargaining council, and then forwarded a request to the negotiating team to develop appropri- ate contract language. Each unit of the university, including the libraries, had an equal opportunity to submit suggestions for negotiable issues.

\section{The Negotiations}

The WSU-AAUP's initial contract documents written in September 1972 referred to only one bargaining unit, with no division of teaching faculty and academic staff. The negotiating team hoped to avoid any internal dissension which was bound to surface if they concurred with the administration's separation of the two groups. In most instances this was done by avoiding the use of classifications within the contract language. Once the team had to present its economic package, however, a decision on the faculty status issue became imperative, especially in developing salary schedules and professional leave clauses. Economics equaled status. Thus, the team chose to take what it felt was the fairest stand, that all bargaining unit members should be termed simply "faculty," a position unacceptable to the university administration, many teaching faculty, and about half of the WSU-AAUP Executive Committee as well. Under pressure from these three groups, then, the negotiating team in October and November 1972 began to modify its contract language to reflect a separate but equal philosophy. Most persuasive in changing the team's attitude was the belief that the contract would not be ratified if an early settlement was not achieved and early settlement would not be possible if the team attempted to negotiate the issue of the reclassification of the academic staff. Compromise was vital. Separate but equal seemed the answer.

The teaching faculty, polled as individuals, generally endorsed the compromise position of the WSU-AAUP negotiating team. The compromise was not accepted, however, by the University Council, a body composed primarily of 
teaching faculty and administrative representatives, and empowered by the Board of Governors to deal with matters concerning the "academic community." (The council allowed the University Libraries only one representative for all librarians and archivists, while it gave teaching departments one representative for each fifteen members. The other 150 academic staff were generally disenfranchised.) The stalemate between the negotiating team and the University Council ultimately produced a reworking of the contract and an attempt at reordering university governance, many aspects of which are still in progress. Peer review and tenure, however, proved to be the most difficult issues to resolve.

\section{Peer Review}

From the beginning of negotiations, the inability of the academic staff to participate in the peer review process, especially in the College of Liberal Arts, made it cumbersome to include the University Council, the faculty's only governing body, in the contract. Yet, at the outset of contract talks, the WSUAAUP hoped to be able to strengthen the role of the University Council by giving it the power to establish guidelines for the peer review of both teaching and nonteaching faculty in matters such as tenure, salaries, promotions, sabbaticals, and other contract concerns relating to university governance. The problem was that the separate-classification-but-equal-rights doctrine advocated by the negotiating team came into conflict with the bylaws and past practices of the University Council. Even though two members of the team were respected members of the council and argued for revision of the bylaws, the council did not grant full membership to the academic staff. The council felt that its main purpose was to promote the interests of the teaching faculty; therefore, librarians and other academic staff should largely be excluded.

During collective bargaining sessions, the university administration's negotiating team developed proposals concerning the peer review of salaries, sabbaticals, and tenure, which skirted the University Council and met WSU-AAUP negotiating demands. The administration suggested that matters subject to peer review be handled by separate peer review committees for both the teaching and the academic staffs, with no formal participation by the council. As a consequence of the council's unwillingness to accept academic staff, the AAUP was obliged to rewrite its contract proposals so as to allow the council to exist outside of the contract as an instrument of university governance. Although currently efforts are still being made to rewrite council bylaws to give full representation to librarians and academic staff, the reluctance of the council to adapt to the changes in its governance responsibility as suggested in the 197273 negotiations probably will mean a continued and more permanent exclusion of the council in matters normally associated with participatory management in higher education. For WSU librarians, this means that full participation in university governance will still be achieved only at the negotiating table.

\section{Tenure}

The initial tenure document developed by the WSU-AAUP in the summer of 1972 gave full faculty tenure privileges to the academic staff. But the university administration countered this attempt to negotiate tenure by submitting a letter of agreement to the WSUAAUP Executive Committee calling for the acceptance of a tenure statute rewritten jointly by the University Council and the university administration. All academic staff, including librarians, were excluded from this document.

The AAUP negotiating team was 
forced to decide whether to accept the rewritten tenure statute or to attempt the negotiation of a new tenure statute. The team's decision to negotiate a new document which would include the academic staff brought about a threat of immediate decertification of the whole WSU-AAUP by a displeased teaching faculty. Again, of major concern to the AAUP team was the rumor that lengthy negotiation probably would jeopardize the team's ability to secure ratification of any negotiated contract. Reluctantly, therefore, the team agreed to submit tenure, for both teaching faculty and academic staff, to further negotiation.

Formal negotiations on tenure began in late January 1973 and continued haphazardly through 1974 . When the basic contract was ratified in June 1973, both sides agreed to a rolling clause which would extend negotiations on the tenure and promotions documents for an additional 120 days. Failing to come to agreement on tenure within the 120 days, the teams decided to continue negotiations through the life of the twoyear contract. When negotiations on a new contract broke down in late June 1974, the university administration withdrew tenure from negotiation because the first contract had expired on June 30 , and therefore the administration felt that it was no longer obligated to negotiate on items in the first contract.

Thus, when contract talks resumed in the fall of 1974, the issues of tenure for academic staff and tenure quotas for both teaching faculty and academic staff remained the key noneconomic issues to be resolved. Through intensive negotiation and finally compromise on both sides, the university agreed in the 1974 contract to offer departmental tenure to academic staff. No tenure quotas for either faculty or academic staff were established, because the AAUP agreed to the continuance of university control over departmental programs and thus, ultimately, over tenure itself. For WSU librarians, this means that they have tenure only within the WSU library system, rather than within the larger university as faculty have.

\section{Elements in the Contracts}

Elements of the contracts which proved especially beneficial to librarians and other academic staff included provisions for past practices, grievance procedures, sabbatical leaves, participation in union activities, and salary and fringe benefits. Librarians, although "separate" from the teaching faculty, were guaranteed equal rights in all these areas.

The total salary increases negotiated for 1972-73 averaged 7 percent, a definite improvement over previous years. For 1973-74 the average salary increase was 6 percent. The new contract for 1974-75 provides for a bargaining unit maximum increase of 10 percent. Eight percent is designated for longevity, promotions, and equity. The remaining 2 percent is based on a cost of living adjustment if necessary. For 1975-76 the across-the-board salary adjustments are 6.5 percent with a maximum ceiling of 9.2 percent, including cost of living. (The cost of living clause, included in the latest contract, is the first to be negotiated by faculty at a major university.)

\section{The Prospects}

A paradox of the union movement at Wayne is that librarians, so active in unionizing, have been more than conservative in using the participatory management powers available to them by the contract. The past practices clause of the contract stipulates that all past practices in matters of university and departmental governance, previously recognized by the WSU Board of Governors and not in violation of provisions of the contract, will continue. By inference, librarians as members of the bargaining unit have an opportunity to 
be more active members of the traditional faculty family than ever before. In essence, since they are part of the bargaining unit, they have the opportunity to participate in matters of self-governance which have long been enjoyed by teaching faculty: a voice in job assignments and research projects and an opportunity to participate in the decision-making process by which the goals of their unit-university libraries -are formulated. To date, librarians have not used these powers.

In the fall of 1965 the library administration, following the example of teaching departments, attempted to involve librarians in the evaluation of their fellow librarians for purposes of deciding salaries, tenure, and promotions. Librarians as a group rejected this offer, preferring to maintain the status quo in which supervisors alone made such decisions. Collective bargaining has not changed this attitude, even though librarians are now required by the contract to have a salary committee which makes recommendations to the library director and ultimately to the university provost on salary increases and merit grants.

Three salary committees have been formed by librarians since ratification of the contract: the first for fiscal 197273 , the second for fiscal 1973-74, and the third for 1974-75. The 1972-73 committee recommended that 46 percent of the eligible librarians be granted selective salary increases. For 1973-74, twenty-eight librarians, 48 percent, were recommended for increases. Significantly, these figures of 46 percent and 48 percent are almost identical to those granted in previous years by the library administration. In addition, the salary committees granted increases to the same individuals as did the supervisors in previous years. A comparison of these increases with those granted in other departments of the university reveals that in no other unit on campus were col- leagues so severe in judgment upon their peers and gave so few selective salary increases.

Since the 1974 contract provided only for across-the-board salary adjustments and special longevity pay, with no selective salary pool, the 1974-75 salary committee was devoted to making recommendations on promotions and women's equity pay adjustments. Like its predecessors, however, the latest salary committee found that evaluation of eligible librarians is a difficult responsibility.

Previously there have been few standards for evaluating librarians. A competent librarian was viewed as one who adequately performed his "nine to five" duties only. Now, as in teaching departments of the university, librarians receive credit for attending professional meetings, publishing articles, and participating in library and university committee work. However, there is still no satisfactory method of evaluating individual job performance. Currently, each librarian annually presents the salary committee with a personal record listing all his professional activities for the given year. In addition, a supervisory evaluation form based on a quantitative rating scale, covering such areas as performance of duties, personal qualities, professional qualities, and administrative ability, is submitted by the immediate supervisor, along with written comments on any corrective measures deemed necessary. Each librarian is given the opportunity to discuss this evaluation with his supervisor and to record any comments in writing.

Because librarians are most unhappy with such evaluative methods, all three salary committees have requested that the Librarians' Assembly establish new guidelines. (The assembly is a quasiofficial parliamentary body composed of all WSU librarians. It was established in 1970 with the expectation that it would provide a vehicle for greater involvement of librarians in both library 
and university governance. Participatory management, like all democracies, depends upon the active participation of each member. But one of the major problems of the assembly has been its lack of decisive action caused by a general lack of interest. The same twenty or twenty-two librarians out of a staff of sixty attend the assembly's bimonthly meetings to discuss critical issues such as guidelines for selective salary increases as well as other issues such as tenure and involvement in university governance.) As a result of these assembly meetings, it was suggested that librarians adopt the method of voluntary peer evaluation, employed successfully in teaching departments, as the alternative method of evaluating individuals for selective salary increases. Less than a third of the professional library staff submitted to this kind of review, even when they could choose their own evaluators from among their peers. In addition, of the twenty-two who submitted to the peer evaluation, only thirteen made the form available to the salary committee, even though it was guaranteed by the contract that all recommendations, accompanied by all materials submitted for review, would be forwarded to the office of the provost unchanged by either the salary committee or the library administration.

Collective bargaining has made WSU librarians unsure of their traditional self-image, as reflected in the lack of forceful leadership by the Librarians' Assembly. The assembly's faithful now seem to be split down the middle on whether librarians are truly to be considered faculty and to be evaluated and treated as such. Half of the WSU librarians are interested only in the "nine to five" job performance issues, while the other half are concerned with making librarianship a more professional endeavor, gauged by involvement in research, publishing, committee membership, and larger university participation.
The inability of the officers of the assembly to get members to agree on either of these positions is a major delay in applying the participatory management provisions of the contract successfully.

The librarians' lack of enthusiastic involvement and decisive action in using the participatory management privileges available to them shows that, in retrospect, the sole issues of salary stability and job security seem to have been librarians' major reasons for so actively unionizing in the first place. For WSU librarians, collective bargaining reinstated many faculty privileges. Individual rights were protected. However, librarians as a group have not profited by negotiations to the fullest extent because they have not used the powers they have been granted. Currently, efforts are being made to make better use of their opportunities. A committee of the assembly convened in the spring of 1974 to review the assembly's bylaws and functions with a view of making recommendations on the means necessary to allow it a more viable role in library and university governance and to provide librarians with more meaningful leadership in using participatory management to their best advantage.

For collective bargaining to be a success for university librarians, careful planning is necessary in choosing a union and participating in negotiations. But the attainment of rights and privileges through negotiation is only the beginning. The effective use of them is the greater challenge.

\section{REFERENCES}

1. Michigan Employment Relations Commission, Decision in the Matter of Wayne State University and the WSU Federation of Teachers, Wayne Medical Faculty Association, WSU Chapter of the American Association of University Professors, WSU Professional and Administrative Association, and WSU Faculty Association (1972), p.145.

2. Ibid., p.146. 